\title{
PENERAPAN METODE PEMBELAJARAN KOOPERATIF NUMBERED HEADS TOGETHER (NHT) UNTUK MENINGKATKAN HASIL BELAJAR DAN BERPIKIR KRITIS SISWA PADA MATA PELAJARAN IPS SD
}

\author{
Erwin Putera Permana \\ erwinp@unpkediri.ac.id \\ Pendidikan Guru Sekolah Dasar \\ Fakultas Keguruan dan Ilmu Pendidikan \\ Universitas Nusantara PGRI Kediri
}

\begin{abstract}
Cooperative Learning Methods Numbered Heads Together (NHT) to review the findings improve learning and Critical Thinking Students in social studies in elementary school. This study is a class action label study. The collected data is the data Students learn critical thinking commercial article. Data collection is done by observation, testing, documentation and questionnaires. Husband research consists From prayer cycle. Cooperative Learning Research Results Numbered Heads Together (NHT) showed an increase in critical thinking skills students learn the commercial article. Process improvement study findings known that i cycle on pre-test activities amounted to $6.25 \% 65.63 \%$ on increased Being a post test activities but still meet requirements yet classical completeness The school set. Taxable income Researchers Repair on the cycle II pre-test activities known that classical learning completeness amounted $15.63 \%$ 93.75\% on increased Being Postal test activities and has been fulfilling requirements set classical completeness The school that is $\geq 75 \%$ by begitu Has Occurred increase mastery learning Grade V amounted to $28.12 \%$ Based on these findings can Execution Model that concluded the implementation of Cooperative Learning Methods Numbered Heads Together (NHT) can Critical Thinking skills improve student learning commercial article.
\end{abstract}

Keywords: Cooperative Learning, Numbered Heads Together (NHT), and students' achievement.

\begin{abstract}
Abstrak: penerapan metode pembelajaran kooperatif Numbered Heads Together (NHT) untuk meningkatkan hasil belajar dan berpikir kritis siswa pada mata pelajaran IPS SD. Penelitian ini merupakan penelitian tindakan kelas. Data yang dikumpulkan adalah data siswa berpikir kritis dan hasil belajar. Pengumpulan data dilakukan dengan cara observasi, tes, dokumentasi dan kuesioner. Penelitian ini terdiri dari dua siklus. Hasil penelitian pembelajaran kooperatif Numbered Heads Together (NHT) menunjukkan peningkatan keterampilan berpikir kritis dan hasil belajar siswa. Proses peningkatan hasil belajar diketahui bahwa siklus I pada kegiatan pre tes sebesar 6,25\% meningkat menjadi $65,63 \%$ pada kegiatan pos tes namun masih belum memenuhi syarat ketuntasan klasikal yang ditetapkan sekolah. Setelah peneliti melakukan perbaikan pada siklus II pada kegiatan pre tes diketahui bahwa ketuntasan belajar klasikal sebesar 15,63\% meningkat menjadi $93,75 \%$ pada kegiatan pos tes dan telah memenuhi syarat ketuntasan klasikal yang ditetapkan sekolah yakni $\geq 75 \%$ dengan begitu telah terjadi peningkatan ketuntasan belajar siswa kelas V sebesar 28,12\% Berdasarkan hasil tersebut dapat disimpulkan bahwa model pelaksanaan penerapan metode pembelajaran
\end{abstract}


Erwin Putera Permana, Penerapan Metode Pembelajaran Kooperatif...

kooperatif Numbered Heads Together (NHT) dapat meningkatkan keterampilan kritis berpikir dan hasil belajar siswa.

Kata kunci : Pembelajaran Kooperatif, Numbered Heads Together (NHT), Berpikir Kritis, Hasil Belajar.

\section{PENDAHULUAN}

Pendidikan adalah usaha sadar dan terencana untuk mewujudkan suasana belajar dan proses pembelajaran agar siswa secara aktif mengembangkan potensi dirinya untuk memiliki kekuatan spiritual keagamaan, pengendalian diri, kepribadian, kecerdasan, akhlak mulia, serta keterampilan yang diperlukan bagi dirinya, masyarakat, bangsa dan negara (Sagala, 2010: 3). Berdasarkan hal tersebut maka pendidikan harus berkualitas artinya dalam pembelajaran, siswa harus mengalami proses pembelajaran secara efektif yang bermakna serta menunjukkan adanya tingkat penguasaan terhadap tugas-tugas belajar sesuai dengan sasaran dan tujuan pendidikan.

Perwujudan pembelajaran yang bermakna salah satunya ditinjau dari keterampilan siswa dalam berbicara. Keterampilan berbicara merupakan salah satu aspek yang harus dikembangkan dalam pendidikan sekolah dasar, siswa dilatih agar mampu menggunakan dan mengekspresikan pemikirannya dengan menggunakan kata dan kalimat yang tepat. Pengembangan keterampilan berbicara pada siswa sekolah dasar lebih menekankan pada pemilihan kata (diksi), keruntutan kata, intonasi membaca kalimat dan ekspresi.

Berdasarkan hasil observasi awal pada SD Kota Blitar saat proses pembelajaran IPS di kelas berjalan kurang efektif khususnya di kelas V meskipun guru sudah menggunakan metode diskusi dan presentasi dengan sederhana karena kondisi kelas yang selalu ramai dan sulit dikendalikan dan ditambah lagi jam pelajaran di waktu siang hari. Selama kegiatan belajar mengajar berlangsung siswa terlihat pasif di kelas, siswa kurang berpartisipasi, kurang aktif dalam proses belajar mengajar, serta ada siswa yang melihat keluar jendela, mengantuk, atau lebih memilih untuk mengerjakan tugas mata pelajaran yang lain daripada memperhatikan penjelasan guru. Pengamatan berikutnya saat guru menggunakan pembelajaran diskusi teman sebangku, siswa bukannya berdiskusi tentang materi yang dibahas tetapi lebih asyik membicarakan hal lain dan bahkan ada yang berlari kesana kemari ke tempat teman lain serta tidak mempunyai tanggung jawab atas pertanyaan diskusi yang telah diberikan oleh guru. Permasalahan pembelajaran inilah yang mengakibatkan aktivitas siswa selama pembelajaran IPS belum mencapai hasil yang maksimal, termasuk hasil belajar yang dicapai dan hal tersebut dapat ditunjukkan dengan nilai ulangan harian dengan jumlah siswa 32 siswa hanya 11 siswa atau 34,3\% siswa yang tuntas serta 21 siswa atau 65,7\% siswa tidak tuntas. Selain permasalahan diatas juga ditemukan bahwa siswa kurang diarahkan untuk berpikir kritis, siswa tidak diajak untuk menemukan konsep tetapi ditunjukkan konsep yang harus selalu diingat, kegiatan pembelajaran terbatas pada kegiatan membaca buku, mendengar penjelasan dan mengerjakan lembar kerja siswa. berdasarkan indikator berpikir kritis ditemukan fakta-fakta lain diantaranya 5 anak atau 15,6\% dari 32 siswa 
Erwin Putera Permana, Penerapan Metode Pembelajaran Kooperatif...

yang mengangkat tangan untuk menjawab pertanyaan guru, siswa merespon pertanyaan dari guru apabila ditunjuk tanpa disertai mengangkat tangan (terpaksa menjawab).

Permasalahan-permasalahan pembelajaran tersebut perlu diselesaikan, sebab pembelajaran IPS di kelas bukan hanya pemberian materi pelajaran, namun sebagai upaya pendidikan untuk menghasilkan manusia seutuhnya. Metode pembelajaran merupakan salah satu komponen penting dalam proses belajar mengajar. Metode pembelajaran pun jika digunakan dengan tepat akan mampu menentukan keberhasilan suatu proses pembelajaran, oleh karena itu dalam penelitian ini peneliti akan mencoba menerapkannya dalam pembelajaran IPS. Metode pembelajaran kooperatif dapat menjadi alternatif agar siswa berkonsentrasi pada materi IPS yang sedang disampaikan oleh peneliti.

Metode pembelajaran kooperatif atau Cooperative Learning, sebagai suatu rangkaian kegiatan belajar di kelas, menekankan kepada konsep berpikir kritis, bersama dan bekerjasama dalam suatu kelompok kecil (3-5 orang siswa yang heterogen), dengan demikian hasil belajar dan berpikir kritis siswa diharapkan dapat meningkat. Metode pembelajaran kooperatif yang akan diterapkan dalam penelitian ini, yaitu dengan menggunakan metode NHT. Menurut Spencer Kagan (dalam Isjoni, 2011:78) NHT merupakan teknik pembelajaran yang memberikan kesempatan pada siswa untuk saling membagikan ide-ide dan pertimbangan jawaban yang paling tepat. Berdasarkan teori tersebut NHT merupakan salah satu teknik pembelajaran yang mengkondisikan siswa untuk mampu memadukan, menarik kesimpulan beragam pikiran dari hasil bertukar gagasan atau pendapat sesama teman dalam kelompoknya. Metode NHT menuntut siswa untuk mampu bertanggungjawab baik secara individu maupun kelompok. Pembelajaran dengan metode NHT menuntut siswa untuk bisa menjawab pertanyaan ketika nomornya dipanggil secara acak oleh peneliti, dimana hal ini dapat menjadi motivasi bagi siswa karena poin yang diperoleh tidak hanya untuk siswa itu sendiri tetapi sekaligus perolehan bagi kelompoknya. Penerapan metode pembelajaran kooperatif NHTini diharapkan dapat memicu siswa untuk mengembangkan pengetahuan serta hasil belajarnya dalam pembelajaran IPS. Berdasarkan latar belakang di atas, permasalahan dalam penelitian ini dirumuskan sebagai berikut: (1) Bagaimanakah Penerapan Metode Pembelajaran Kooperatif NHT pada Mata Pelajaran IPS SD; (2) Apakah Penerapan Metode Pembelajaran Kooperatif NHT dapat Meningkatkan Hasil Belajar dan Berpikir Kritis Siswa pada Mata Pelajaran IPS SD?

Hasil dari penelitian ini diharapkan dapat memberikan manfaat: (1) Bagi sekolah, bisa dijadikan bahan pertimbangan dan gagasan untuk mengkaji berbagai metode pembelajaran yang mendukung efektivitas belajar mengajar. (2) Bagi guru IPS, bisa digunakan sebagai bahan informasi untuk menerapkan metode yang tepat dalam meningkatkan partisipasi siswa dalam proses belajar IPS sehingga tercipta pembelajaran yang efektif, efisien dan sesuai standar kompetensi yang diharapkan. (3) Bagi siswa, diharapkan mampu menjadikan siswa mendapatkan prestasi yang lebih baik. (4) Bagi 
Erwin Putera Permana, Penerapan Metode Pembelajaran Kooperatif...

peneliti, bisa digunakan sebagai sumber informasi untuk dipergunakan sebagai acuan dalam penelitian selanjutnya serta sebagai pengetahuan dan pengalaman dalam mempersiapkan diri sebagai pendidik nantinya

\section{METODE PENELITIAN}

Penelitian ini menggunakan pendekatan kualitatif. Jenis penelitian yang dilakukan adalah penelitian tindakan kelas (Classroom Action Research). Penelitian tindakan kelas ini bertujuan untuk memperbaiki dan meningkatkan kualitas pembelajaran. Penelitian ini dilaksanakan dalam siklus-siklus, dalam setiap siklus meliputi 4 tahapan yaitu: perencanaan, pelaksanaan, pengamatan dan refleksi. Apabila sudah diketahui letak keberhasilan dan hambatan dari tindakan yang dilaksanakan pada siklus I, peneliti menentukan rancangan untuk siklus II.

Peran peneliti yaitu sebagai pengamat, perencana, pelaksana, pengumpul data, penganalisis data dan melaporkan hasil penelitiannya tersebut. Peneliti dibantu oleh guru mata pelajaran IPS yang mengajar di kelas V SDN Kota Blitar sebagai observer.

Subjek penelitian ini adalah kelas V SDN Kota Blitar dengan jumlah siswa sebanyak 32 siswa yang terdiri dari 18 siswi perempuan dan 14 siswa laki-laki. Peneliti memilih kelas $\mathrm{V}$ sebagai subjek penelitian karena berdasarkan hasil pengamatan ditemukan bahwa nilai mata pelajaran IPS di kelas V banyak yang belum tuntas. Kedua, kelas $\mathrm{V}$ masih pasif dan kurang berpatisipasi aktif dalam berpikir kritis dalam proses pembelajaran berlangsung.

Analisis kualitatif dalam penelitian ini dilakukan terhadap kemampuan berpikir kritis, observasi, dokumentasi, dan respon siswa. Sedangkan analisis kuantitatif dilakukan pada hasil belajar siswa. Analisis kualitatif pada penelitian ini bersifat menggambarkan kenyataan atau fakta yang dicapai siswa juga untuk memperoleh respon siswa terhadap proses pembelajaran. Analisis data dilakukan sekali dalam setiap siklus.

Analisis ini dihitung dengan menggunakan stastistik sederhana yaitu:

Keterlaksanaan pembelajaran model problem solving dengan media audiovisual. Lembar observasi memuat indikator yang harus tampak pada pembelajaran model problem solving dengan media audio-visual. Data kemudian diolah sehingga diperoleh persentase dengan rumus.

$\%$ keterlaksanaan pembelajaran $=\frac{\sum \text { Indikator keterlaksanaan }}{\sum \text { Seluruh Indikator }} \times 100 \%$

Data hasil observasi berpikir kritis memuat butir-butir yang harus tampak pada proses pembelajaran dan masing-masing butir diskor. Data yang berupa skor kemudian diolah sehingga diperoleh persentase dengan rumus.

$$
\% \text { Kemampuan berpikirkritis }=\frac{\text { Skor yang diperoleh }}{\text { Skor maksimal }} \times 100 \%
$$


Erwin Putera Permana, Penerapan Metode Pembelajaran Kooperatif...

Data hasil belajar siswa berdasarkan hasil tes yang diberikan setiap siklus. Hasil belajar dapat dilihat berdasarkan:

Ketuntasan klasikal, siswa dianggap telah tuntas belajar apabila mencapai $85 \%$ dari jumlah siswa yang mencapai daya serap $\geq 70$. Untuk mengetahui hasil belajar siswa secara klasikal (TBk) menggunakan rumus sebagai berikut:

$$
T B k=\frac{\sum \text { siswa } \text { yang memperoleh skor } \geq 70}{\sum \text { seluruh sisweterangan: }} \times 100 \%
$$

TBk : ketuntasan belajar secara klasikal

Ketuntasan individu, siswa dianggap tuntas belajar apabila daya serap mencapai $\geq 70$. Apabila daya serap kurang dari 70, maka siswa masuk dalam program perbaikan. Untuk mengetahui hasil belajar siswa secara perorangan dapat menggunakan rumus berikut.

$$
\text { Skor }=\frac{\sum \text { Nilai } L K K+\sum \text { Nilai Tes Akhir }}{\sum \text { Nilai maksimal }} \times 100
$$

Apabila persentase ketuntasan klasikal belum mencapai $85 \%$, maka penelitian dilanjutkan pada siklus kedua, dan seterusnya ke siklus ketiga jika kriteria tersebut belum terpenuhi pada siklus kedua.

Prosedur penelitian ini berbentuk siklus. Dengan mengacu pada model Kemmis dan McTaggart (dalam Arikunto, 2007), setiap siklus terdiri atas empat kegiatan pokok, yakni perencanaan tindakan, pelaksanaan tindakan, observasi, dan refleksi sebagaimana tampak pada gambar berikut:

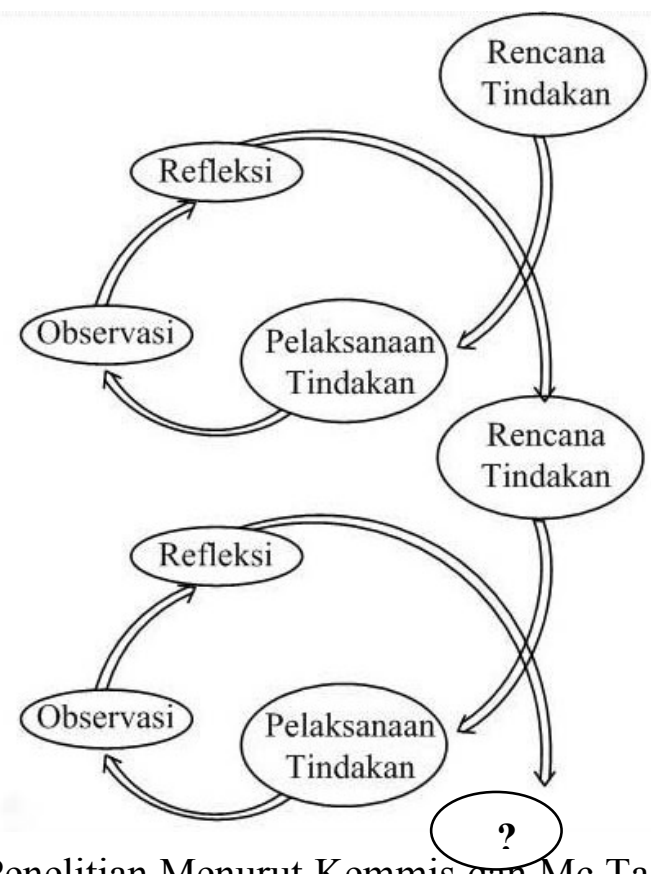

Bagan Visualisasi Penelitian Menurut Kemmis can Mc Taggart dalam Arikunto, 2007 
Erwin Putera Permana, Penerapan Metode Pembelajaran Kooperatif...

\section{HASIL}

Berdasarkan hasil pengamatan observer selama pelaksanaan tindakan penerapan metode pembelajaran kooperatif NHT siklus I, ditemukan sebagian besar indikator dalam deskripsi pelaksanaan tindakan penelitian (kegiatan pembelajaran) sudah tercapai dalam pelaksanaan tindakan siklus I. Ketercapaian indikator dalam deskripsi pelaksanaan tindakan kegiatan penelitian tersebut dapat dilihat dari analisis lembar observasi. Hasil analisis menunjukkan bahwa 91,67 \% indikator dalam deskripsi pelaksanaan tindakan kegiatan penelitian (kegiatan pembelajaran) sudah tercapai. Sedangkan selama pelaksanaan tindakan penerapan metode pembelajaran kooperatif NHT siklus II, dapat dikatakan sebagian besar indikator dalam deskripsi pelaksanaan tindakan penelitian (kegiatan pembelajaran) sudah tercapai dalam pelaksanaan tindakan siklus II. Ketercapaian indikator dalam deskripsi pelaksanaan tindakan kegiatan penelitian tersebut dapat dilihat dari analisis lembar observasi. Hasil analisis menunjukkan bahwa $100 \%$ indikator dalam deskripsi pelaksanaan tindakan kegiatan penelitian (kegiatan pembelajaran) sudah tercapai. Pada siklus II ini, kerjasama siswa dalam kelompok juga meningkat, masing-masing siswa sudah mempunyai tanggung jawab sendiri atas tugas yang diberikan kepada dirinya sendiri maupun kepada kelompoknya. Siswa juga sudah berani bertanya, menanggapi serta berpendapat atas pertanyaan-pertanyaan yang telah diberikan. Siswa juga sudah menghargai pendapat temannya saat diskusi berlangsung. Siswa juga sudah terlibat aktif dalam diskusi kelompok, serta sudah mencatat apa yang telah didiskusikan oleh kelompok lain.

Tabel 1 Perbandingan Keterlaksanaan Penerapan Metode Pembelajaran Kooperatif dengan NHT pada Siklus I dan Siklus II

\begin{tabular}{|l|l|l|}
\hline TP I & TP II & Keterangan \\
\hline $91,67 \%$ & $100 \%$ & Meningkat \\
\hline
\end{tabular}

Berdasarkan tabel 1 perbandingan tentang keterlaksanaan penerapan metode pembelajaran kooperatif NHT dari siklus I sebesar 76\% naik menjadi $89 \%$ pada siklus II.

Berdasarkan penerapan metode pembelajaran kooperatif NHT yang dilakukan peneliti pada siklus I dan siklus II telah menunjukkan hasil belajar siswa mengalami peningkatan. Perbandingan hasil belajar siswa secara klasikal siklus I dan siklus II disajikan dalam Tabel 2 berikut:

Tabel 2 Perbandingan Hasil Belajar Siswa secara Klasikal Siklus I dan Siklus II Siswa Kelas V SD Kota Blitar

\begin{tabular}{|c|c|c|c|c|c|}
\hline \multirow{2}{*}{ Siklus } & \multirow{2}{*}{ Hasil belajar } & \multicolumn{3}{|c|}{ Ketuntasan Belajar Klasikal } & \multirow{2}{*}{ Keterangan } \\
\cline { 3 - 5 } & $\begin{array}{c}\sum \text { Siswa Belum } \\
\text { Tuntas }\end{array}$ & $\begin{array}{c}\sum \text { Siswa } \\
\text { Tuntas }\end{array}$ & $\begin{array}{c}\text { Presentase } \\
\text { Ketuntasan }\end{array}$ & \\
\hline \multirow{2}{*}{ Siklus I } & Pre tes & 30 & 2 & $6,25 \%$ & \multirow{2}{*}{ Meningkat } \\
\cline { 2 - 5 } & Post tes & 11 & 21 & $65,63 \%$ & \\
\hline
\end{tabular}


Erwin Putera Permana, Penerapan Metode Pembelajaran Kooperatif...

\begin{tabular}{|c|c|c|c|c|c|}
\hline \multirow{2}{*}{ Siklus II } & Pre tes & 27 & 5 & $15,63 \%$ & \multirow{2}{*}{ Meningkat } \\
\cline { 2 - 5 } & Post tes & 2 & 30 & $93,75 \%$ & \\
\hline
\end{tabular}

Berdasarkan Tabel 4.8 di atas dapat diketahui bahwa ketuntasan belajar siswa secara klasikal kelas V siklus I pada kegiatan pre tes sebesar 6,25\% meningkat menjadi $65,63 \%$ pada kegiatan pos tes namun masih belum memenuhi syarat ketuntasan klasikal yang ditetapkan sekolah. Setelah peneliti melakukan perbaikan pada siklus II pada kegiatan pre tes diketahui bahwa ketuntasan belajar klasikal sebesar 15,63\% meningkat menjadi 93,75\% pada kegiatan pos tes dan telah memenuhi syarat ketuntasan klasikal yang ditetapkan sekolah yakni $\geq 75 \%$ dengan begitu telah terjadi peningkatan ketuntasan belajar siswa kelas V sebesar 28,12\%.

\section{PEMBAHASAN}

Penerapan metode pembelajaran kooperatif NHT sudah terlaksana dengan baik, akan tetapi dalam kegiatan inti yaitu ketika guru menjelaskan dan ketika proses pembelajaran dengan metode NHT berjalan kurang lancar, karena masih banyak sebagaian siswa yang ramai sendiri, bercanda, bergurau bersama temannya saat kegiatan pembelajaran berlangsung. Begitu juga saat diskusi bersama dengan metode NHT, sebagian kelompok ada yang belum selesai mengerjakan tugas kelompoknya dalam waktu yang ditentukan, karena ada beberapa anggota kelompok yang tidak ikut mengerjakan, masih banyak yang kurang serius dalam belajar dan banyak yang ramai sendiri. Sebagian siswa tidak memperhatikan dan belum aktif berpikir kritis dan mengemukakan pendapat mereka saat mempresentasikan hasil diskusi mereka karena merasa takut dan tidak percaya diri. Padahal metode ini diterapkan agar siswa mampu berpikir kritis dan memahami materi dengan bertukar gagasan dan pikiran dari diskusi kelompok, mampu mengungkapkan pendapat mereka dengan penuh percaya diri dan tidak takut. Agar pembelajaran tetap berjalan kondusif guru selalu memberikan pengertian agar semua siswa mengerjakan dan berdiskusi menurut kelompoknya dan memperingatkan kepada semua siswa jangan ramai sendiri karena jika ramai sendiri tidak akan memahami materi yang diberikan dan pekerjaannya tidak akan selesai.

Penerapan metode pembelajaran kooperatif NHT yang dilakukan oleh peneliti pada siklus II sudah lebih baik dari siklus I. Pada siklus II proses pembelajaran sudah berjalan dengan lancar. Kondisi dan situasi kelas saat proses pembelajaran juga sudah kondusif dimana siswa sudah tidak ramai sendiri dan mampu berpikir kritis saat proses pembelajaran dilaksanakan. Peningkatan kemampuan berpikir kritis dilihat dari respon siswa dengan indikator banyak siswa yang aktif bertanya dan antusias ketika mereka kurang mengerti penjelasan dari guru. Begitu juga saat diskusi bersama menggunakan metode NHT, kerjasama siswa dalam kelompok juga sudah meningkat terlihat semua anggota kelompok saling bertukar pikiran dan mempertimbakan jawaban yang tepat, masing-masing siswa sudah mempunyai tanggung jawab sendiri atas tugas yang 


\section{Erwin Putera Permana, Penerapan Metode Pembelajaran Kooperatif...}

diberikan kepada dirinya sendiri maupun kepada kelompoknya. Siswa juga sudah berani bertanya, menanggapi serta berpendapat atas pertanyaan-pertanyaan yang telah diberikan. Siswa juga sudah menghargai pendapat temannya saat diskusi berlangsung. Siswa juga sudah terlibat aktif dalam diskusi kelompok, semua siswa juga sudah menyampaikan pikirannya tanpa rasa takut dan penuh percaya diri. Guru juga memberikan reward kepada semua siswa yang aktif dalam bentuk poin berupa bintang. Peningkatan penerapan yang telah dijabarkan tersebut sesuai dengan teori yang disebutkan oleh Kagan (2011) Numbered Heads Together yaitu teknik pembelajaran yang memberikan kesempatan kepada siswa untuk saling membagikan ide-ide dan pertimbangan jawaban yang paling tepat dan mendorong siswa untuk meningkatkan semangat kerjasama mereka.

Berdasarkan analisis data hasil belajar siswa yang telah dilakukan oleh peneliti baik pada siklus I dan II, penerapan metode pembelajaran kooperatif NHT terbukti mampu meningkatkan hasil belajar dan berpikir kritis siswa.

Hasil belajar siswa kelas V SDN Kota Blitar dianalisis berdasarkan nilai tes yaitu terdiri dari pre tes dan pos tes yang diberikan pada tiap siklus. Hasil belajar siswa pada siklus I sudah cukup baik dikarenakan adanya peningkatan dari nilai pre tes ke pos tes, pada siklus I ketika pre tes nilai rata-rata siswa masih dibawah KKM sedangkan ketika pos tes nilai rata-rata siswa sudah berada diatas KKM yang sudah ditentukan meskipun belum mencapai ketuntasan secara klasikal. Begitu juga dengan hasil belajar siswa pada siklus II yang mengalami peningkatan dari nilai pre tes ke pos test dan sudah mencapai ketuntasan secara klasikal. Peningkatan nilai pre tes dan pos tes dari siklus I ke siklus II ini disebabkan karena saat pre tes siswa belum mengerti dan memahami materi yang diajarkan sehingga siswa mengerjakan tes hanya sebatas pengetahuan mereka sedangkan saat siswa mengerjakan pos tes mereka sudah mengetahui dan memahami materi yang diajarkan. Siswa mengetahui dan memahami materi pelajaran karena mereka saling bertukar pikiran, memperdalam pemahaman mereka dari diskusi kelompok yang diterapkan dengan metode NHT yang diterapkan selama proses pembelajaran. Sehingga siswa lebih memahami materi dari interaksi bersama kelompok dan siswa lebih mudah dalam mengerjakan soal pos tes yang diberikan sehingga terbukti nilai pos tes siswa dari siklus I dan siklus II mengalami peningkatan yang baik. Hal tersebut juga sesuai dengan yang diungkapkan Hill (dalam Ericka 2010), bahwa kelebihan belajar dengan metode NHT dapat meningkatkan prestasi siswa, memperdalam pemahaman siswa, menyenangkan siswa dalam belajar, mengembangkan sikap positif siswa, mengembangkan sikap kepemimpinan siswa, mengembangkan rasa percaya diri siswa, mengembangkan rasa saling memiliki, mengembangkan keterampilan berpikir kritis untuk masa depan. Selain itu, soal tes yang digunakan dalam penelitian ini hanya jenis soal tes yang mempunyai kriteria sedang dan mudah sehingga siswa lebih mudah untuk mengerjakan soal pos tes. 
Erwin Putera Permana, Penerapan Metode Pembelajaran Kooperatif...

\section{KESIMPULAN DAN SARAN \\ Simpulan}

Berdasarkan hasil analisis dan pembahasan, dapat disimpulkan sebagai berikut.

(1) Pelaksanaan penerapan metode pembelajaran kooperatif dengan teknik Numbered Heads Together (NHT) pada mata pelajaran IPS SD telah berhasil diterapkan dengan baik, hal ini ditunjukkan dengan peningkatan ketercapaian hasil tindakan dalam siklus I dan II. (2) Penerapan metode pembelajaran kooperatif dengan teknik Numbered Heads Together (NHT) dapat meningkatkan hasil belajar siswa pada mata pelajaran IPS SD. Hasil belajar siswa dari siklus I dan II mengalami peningkatan baik dari nilai rata-rata kelas dan ketuntasan belajar siswa.

\section{Saran}

Berdasarkan kesimpulan yang diperoleh, maka saran yang dapat diberikan sebagai berikut. (1) Bagi sekolah penerapan metode pembelajaran kooperatif Numbered Heads Together (NHT) dapat digunakan sebagai pertimbangan pengembangan strategi pembelajaran bagi mata pelajaran yang lain. Sekolah juga disarankan untuk mengadakan workshop tentang penerapan metode serta teknik pembelajaran yang lebih inovatif dan kreatif lainnya sehingga dapat meningkatkan mutu pendidikan di SD Kota Blitar. (2) Bagi Guru Mata Pelajaran IPS di SDN Kota Blitar disarankan untuk menerapkan metode pembelajaran kooperatif Numbered Heads Together (NHT) yang disesuaikan dengan materi pembelajaran yang bersifat memahami serta mengaplikasikan atau memecahkan masalah karena tidak semua materi bisa menggunakan metode NHT. (3) Bagi peneliti lain dapat dijadikan bahan masukan dan referensi serta diharapkan dalam membuat intrumen soal tes lebih baik soal tes yang digunakan mempunyai tingkat kesukaran butir soal yang sulit dengan begitu hasil dari penerapan metode pembelajaran dengan terknik tersebut dapat optimal.

\section{DAFTAR RUJUKAN}

Arikunto, Suharsimi. 2009. Dasar-Dasar Evaluasi Pendidikan. Jakarta: PT Bumi Aksara.

Arikunto, dkk. 2008. Penelitian Tindakan Kelas. Jakarta: PT Bumi Aksara

Budiningsih, C. Asri. 2005. Belajar dan Pembelajaran, Yogyakarta: Rineka Cipta.

Dimyati \& Mudjiono. 2006. Belajar dan Pembelajaran. Jakarta: PT Rineka Cipta

Fatkhullah, Mukhammad. 2011. Perbaikan Mutu Pendidikan Di Indonesia: Betulkah Begini Caranya?, (Online), (http://fattah-fisip11.web.unair.ac.id/artikel-detail62930-Jejak Opini- Perbaikan Mutu Pendidikan Di Indonesia: Betulkah Begini Caranya.html), diakses tanggal 14 Desember 2012.

Ibrahim, Muslimin., dkk 2005. Pembelajaran Kooperatif. Surabaya: University Press Unesa

Isjoni. 2011. Cooperative Learning Efektivitas Pembelajaran Kelompok. Bandung: Alfabeta 
Erwin Putera Permana, Penerapan Metode Pembelajaran Kooperatif...

Kunandar. 2011. Guru Profesional Implementasi Kurikulum Tingkat Satuan Pendidikan (KTSP) dan Sukses dalam Sertifikasi Guru. Jakarta: Rajawali Pers.

Mulyasa. 2007. Kurikulum Tingkat Satuan Pendidikan. Bandung: Remaja Rosda Karya.

Nurhadi, dkk. 2004. Pembelajaran Kontekstual dan Penerapannya dalam KBK. Malang: UM Press

Sagala, Syaiful, 2005. Konsep dan Makna Pembelajaran. Jakarta: PT Rineka Cipta

Slameto. 2003. Belajar dan Faktor-faktor yang Mempengaruhinya. Jakarta: PT Rineka Cipta

Suprijono, Agus. 2009. Cooperative Learning. Surabaya: Pustaka Pelajar

Sudjana, Nana. 2010. Penilaian Hasil Proses Belajar Mengajar. Bandung: PT Remaja Rosdakarya

Rustini, Tin. 2008. Penerapan Model Problem Solving untuk Meningkatkan Pengembangan Potensi Berpikir Siswa Dalam Pembelajaran IPS di Sekolah Dasar. Jurnal (diakses 27 februari 2012)

Winkel, W.S. 1996. Psikologi Pengajaran. Jakarta: Grasindo 